\title{
Prediction of acute renal failure after birth asphyxia
}

\author{
D S Roberts, G B Haycock, R N Dalton, C Turner, P Tomlinson, L Stimmler, J W Scopes
}

\begin{abstract}
Twenty one babies of 34-41 weeks' gestational age with birth asphyxia (5 minute Apgar score $\leqslant 5$ or umbilical artery $\mathrm{pH} \leqslant 7 \cdot 2$ ) were studied during the first two days of life to find out whether the urinary excretion of tubular markers of renal function is of value in the early diagnosis of acute renal failure. Urinary retinol binding protein, myoglobin, and N-acetyl- $\beta$-D-glucosaminidase (NAG), expressed as a ratio with urinary creatinine, were measured and excretion profiles repeated at 3-6 days in 15 infants and at 7-14 days in 11 infants. Plasma creatinine concentration, creatinine clearance, plasma myoglobin concentration, and fractional sodium excretion were measured where possible in asphyxiated infants. Control data were obtained from $\mathbf{5 0}$ healthy infants: 28 gave urine samples alone, 17 urine and blood, and five blood alone. Normal urinary values were derived from 17, 25 , and three infants, respectively, for the three time periods. The number of control samples was limited for ethical reasons.
\end{abstract}

Four asphyxiated infants had acute renal failure (group 1), four had tubular dysfunction without glomerular disturbance (group 2) and 13 had normal renal function (group 3). Group 1 were clearly identified by greatly increased urinary retinol binding protein $(>27000$ $\mu \mathrm{g} / \mathrm{mmol}$ creatinine) and myoglobin $(>1500$ $\mu \mathrm{g} / \mathrm{mmol}$ creatinine) excretion measured in the first two days of life. In control infants the range of excretion of retinol binding protein within the same time period was 3 to 967 $\mu \mathrm{g} / \mathrm{mmol}$ creatinine and urinary myoglobin was undetectable. Excretion of NAG failed to discriminate between groups 1 and 2 . Acute renal failure occurred only in infants who had heavy myoglobinaemia. Tubular dysfunction in group 2 was transient and not accompanied by plasma electrolyte disturbances.

We conclude that measurement of urinary excretion of retinol binding protein or myoglobin after birth is helpful in the early diagnosis of acute renal failure.

Acute renal failure is a recognised complication of birth asphyxia; it carries a poor immediate prognosis and may result in permanent renal damage in up to $40 \%$ of survivors. ${ }^{1-6}$ The recent reports of increased urinary excretion of $\beta_{2}$ microglobulin in infants with evidence of intrauterine fetal distress (meconium stained liquor) by Cole $e t$ al, and in sick infants by Tack et al, led these authors to suggest that subclinical, hypoxic, renal damage may be a relatively common, underdiagnosed finding. ${ }^{78}$

The early recognition of acute renal failure is particularly important in asphyxiated infants with hypoxic encephalopathy, in whom a stable biochemical milieu is vital, because it facilitates the administration of appropriate fluid and electrolyte replacement. The diagnosis is frequently difficult to make, however, because many of the clinical and biochemical findings that are helpful in establishing the diagnosis of acute renal failure in adults and children are unreliable in neonates. The presence or absence of oliguria may be misleading as $7 \%$ of healthy babies fail to pass urine until the second day of life, ${ }^{9}$ and non-oliguric acute renal failure has been reported in neonates. The plasma creatinine concentration on day 1 is a poor guide to an infant's renal function, because it mainly reflects the maternal creatinine concentration. ${ }^{11} 12 \mathrm{~A}$ further difficulty in the interpretation of the plasma creatinine concentration is that the methods of measurement in common use (modifications of the colorimetric Jaffé reaction) are subject to errors from interfering chromogens such as bilirubin and pyruvate, ${ }^{13}$ substances that are likely to be present in increased concentrations in the blood of sick infants. The value of indexes such as the urine:plasma concentration ratio of sodium, creatinine, and urea are limited by the overlap that exists between infants with functional (prerenal) failure, and those with intrinsic renal failure. ${ }^{14-16}$ The fractional excretion of sodium or renal failure index may be of diagnostic value, but both need to be interpreted with caution in the preterm, ${ }^{17}$ and in infants who have been given a saline challenge or treated with diuretics or aminophylline.

Myoglobinuria is a cause of renal failure in adults, ${ }^{18}$ and a strong correlation between the duration of postnatal oliguria and the severity of myoglobinaemia has been reported in asphyxiated infants. ${ }^{19}$ The presence of myoglobinuria may therefore be a useful indicator of acute renal failure. ${ }^{20}$

This study was designed to investigate the value of measurements of the excretion of retinol binding protein, myoglobin, and $\mathrm{N}$ acetyl- $\beta$-D-glucosaminidase (NAG) during the first two days of life as predictors of clinically important acute renal failure after birth asphyxia, and to follow the excretion profiles into the second week of life.

Patients and methods

Twenty one infants who had had an episode of birth asphyxia, defined as a 5 minute Apgar 
score of 5 or below, or an umbilical artery $\mathrm{pH}$ of $7 \cdot 2$ or below at delivery, were studied in the neonatal units of these hospitals. The study was approved by the ethics committees of both hospitals and parental consent was obtained in all cases. Infants were managed according to the standard protocols used in the two units, no modifications being made as a result of participation in the study.

Causes of birth asphyxia included severe shoulder dystocia, intrapartum cord traction, and haemorrhage. Sepsis was implicated in the cause in only one infant, delivered in poor condition at 36 weeks, whose cultures yielded Listeria monocytogenes after $\mathbf{4 8}$ hours' incubation.

All infants were of 34 weeks' gestational age or above. This lower limit was chosen because nephronogenesis is complete by this time and comparisons are not usually complicated by developmentally determined differences in renal function. ${ }^{21}$ Gestational age was assessed from the menstrual history, ultrasonography, or by the clinical criteria of Dubowitz et al. 22

Wherever possible, infants were studied on several occasions during the first two weeks of life and results grouped into three postnatal time periods: $1-2$ days, 3-6 days, and 7-14

Table 1 Number of infants in each group providing samples for each analysis at each time period

\begin{tabular}{|c|c|c|c|c|c|c|}
\hline \multirow[t]{3}{*}{ Analysis } & \multirow{2}{*}{\multicolumn{3}{|c|}{$\begin{array}{l}\text { Asphyxiated infants } \\
(n=21)\end{array}$}} & \multirow{2}{*}{\multicolumn{3}{|c|}{$\begin{array}{l}\begin{array}{l}\text { Control infants* } \\
(n=50)\end{array} \\
\text { Time period (days) }\end{array}$}} \\
\hline & & & & & & \\
\hline & $1-2$ & $3-6$ & $7-14$ & $1-2$ & $3-6$ & $7-14$ \\
\hline $\begin{array}{l}\text { Retinol binding protein } \\
\text { Urinary myoglobin } \\
\text { N-acetyl- } \beta \text {-D-glucosaminidase } \\
\text { Urine output } \\
\text { Plasma creatinine } \\
\text { Creatinine clearance } \\
\text { Plasma myoglobulin } \\
\text { Fractional excretion of sodium }\end{array}$ & $\begin{array}{l}21 \\
21 \\
21 \\
19 \\
21 \\
19 \\
20 \\
19\end{array}$ & $\begin{array}{r}15 \\
15 \\
15 \\
0 \\
14 \\
14 \\
14 \\
14\end{array}$ & $\begin{array}{r}11 \\
11 \\
11 \\
0 \\
10 \\
9 \\
8 \\
9\end{array}$ & $\begin{array}{r}17 \\
17 \\
17 \\
0 \\
4 \\
0 \\
4 \\
4\end{array}$ & $\begin{array}{r}27 \\
27 \\
27 \\
0 \\
13 \\
0 \\
14 \\
11\end{array}$ & $\begin{array}{l}3 \\
3 \\
3 \\
0 \\
3 \\
0 \\
3 \\
2\end{array}$ \\
\hline
\end{tabular}

${ }^{*}$ Of the 50 control infants, 28 gave urine samples, five gave blood samples, and 17 gave both.

Table 2 Clinical data of infants studied on days 1-2. Values are expressed as geometric mean (range)

\begin{tabular}{|c|c|c|c|}
\hline & $\begin{array}{l}\text { Asphyxiated } \\
\text { infants } \\
(n=21)\end{array}$ & $\begin{array}{l}\text { Control } \\
\text { infants (days } 1-2) \\
(n=17)\end{array}$ & $p$ Value ${ }^{*}$ \\
\hline $\begin{array}{l}\text { Gestational age (weeks) } \\
\text { Birth weight (g) }\end{array}$ & $\begin{array}{l}39 \cdot 3(34-41) \\
3400(2200-4800)\end{array}$ & $\begin{array}{l}37 \cdot 7(34-41) \\
3400(1900-4700)\end{array}$ & $\begin{array}{l}\text { NS } \\
\text { NS }\end{array}$ \\
\hline $\begin{array}{l}\text { Apgar score: } \\
\text { At } 1 \text { minute } \\
\text { At } 5 \text { minutes }\end{array}$ & $\begin{array}{l}2 \cdot 3(0-7) \\
4 \cdot 1(0-9)\end{array}$ & $\begin{array}{l}8 \cdot 6(6-10) \\
9 \cdot 6(8-10)\end{array}$ & $\begin{array}{l}<0.01 \\
<0.01\end{array}$ \\
\hline
\end{tabular}

*Wilcoxon rank sum test with Bonferroni correction. days. All infants were studied within the first two days of life and measurements were repeated between 3-6 days in 15, and in the second week of life in 11 infants. It was not possible to repeat measurements in some infants because of death or discharge.

A total of 50 non-asphyxiated infants served as controls for the study; 28 provided urine samples, 17 both urine and blood samples, and five urine samples alone. Seventeen control urine specimens were available for analysis during the first two days of life, 27 during the 3-6 day period, and three during the period 7-14 days. With the exception of two infants who provided urine samples on different days, non-asphyxiated infants were studied on a single occasion.

Blood samples from all infants were obtained when blood was drawn for clinical purposes, and data are limited for this reason. The numbers of individual analyses are shown in table 1. Plasma was separated immediately and stored at $-20^{\circ} \mathrm{C}$ until analysis. Urine was collected by the method of Tarlow and also stored at $-20^{\circ} \mathrm{C} .{ }^{23}$ None of the infants studied was treated with aminoglycosides, which may affect tubular function. ${ }^{24} 25$

Glomerular function was estimated by the plasma creatinine concentration and endogenous creatinine clearance (calculated as urine creatinine concentration $\times$ urine flow rate $(\mathrm{ml} / \mathrm{min}) /$ plasma creatinine concentration). Tubular performance was assessed by the urinary concentrations of retinol binding protein, NAG, and myoglobin, divided by the urinary creatinine concentration. Fractional excretion of sodium (calculated as the urine:plasma sodium ratio/ urine:plasma creatinine ratio) was also measured, and results are reported when diuretics were not administered.

Sodium was estimated in plasma and urine by flame photometry. Creatinine was measured in plasma by high performance liquid chromatography with cation exchange (HPLC), ${ }^{26}$ and in urine by an automated, reaction rate version of the Jaffé reaction. ${ }^{27}$ Retinol binding protein and myoglobin were measured in urine by enzyme linked immunosorbent assays (ELISA) using rabbit antisera (Dako Ltd). ${ }^{28}$ (Retinol binding protein ELISA: $P$ Tomlinson, personal communication, myoglobin ELISA: D Roberts, unpublished observations). Myoglobin in plasma was also estimated by ELISA. The limit of detection for both assays was $2 \mu \mathrm{g} / \mathrm{l}$. NAG

Table 3 Results of biochemical tests done during first two days of life. Values expressed as geometric mean (range)

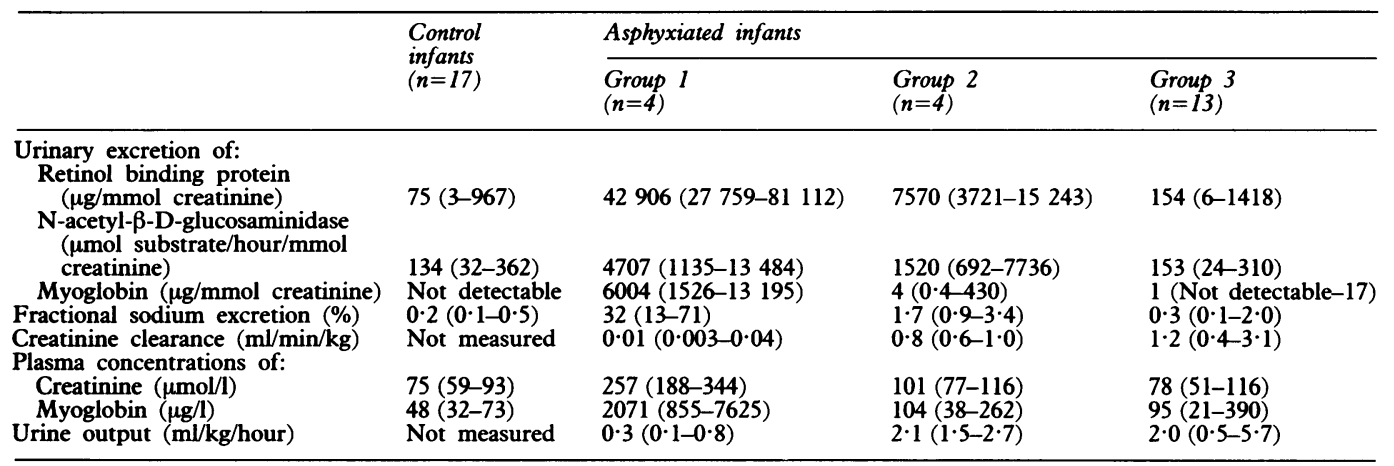




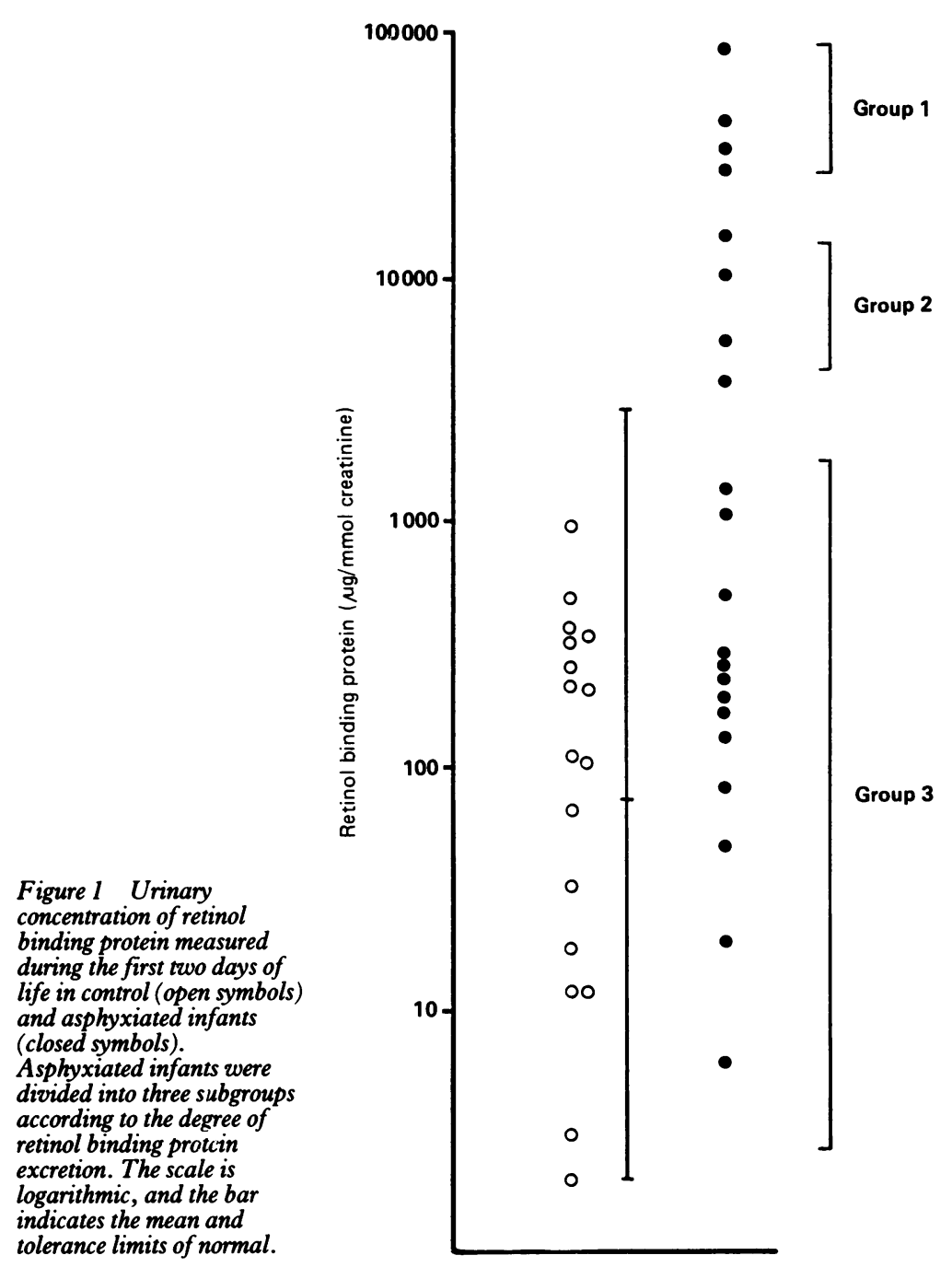

tolerance limits of normal.
Results

Table 2 shows the clinical data of the study infants on days 1-2. There were no significant differences in gestational age or birth weight between the asphyxiated infants and controls.

Four asphyxiated infants (19\%) developed acute renal failure (defined as a plasma creatinine concentration of over $130 \mu \mathrm{mol} / \mathrm{l}$ for at least two consecutive days). One infant required treatment with peritoneal dialysis for hyperkalaemic dysrhythmia.

Nine infants $(43 \%)$ had asphyxial encephalopathy with seizures and seven of these had some degree of renal dysfunction (three had acute renal failure, and four had tubular proteinuria). A further six infants $(29 \%)$ had transient cerebral irritability and feeding problems, but only one of these infants developed acute renal failure. Six infants who had no cerebral symptoms had normal renal function. Three infants died (14\%), two during the course of the study, at 2 and 10 days of age, respectively.

The relevant biochemical data of the study infants on days 1-2 are shown in table 3. The upper tolerance limits of normal for retinol binding protein and NAG were defined as the geometric mean plus two logarithmic SDs for the respective set of control data. These were $2968 \mu \mathrm{g} / \mathrm{mmol}$ creatinine and $465 \mu \mathrm{mol}$ substrate/hour/mmol creatinine, respectively. Myoglobin was undetectable in the urine of healthy newborns on days $1-2$.

When the urinary retinol binding protein:
Figure 2 Plasma creatinine concentrations with increasing postnatal age in control subjects open symbols) and the three subgroups of asphyxiated infants (closed symbols-group 1: circles, group 2: triangles, and group 3: squares). The horizontal bars indicate the mean for each group. 


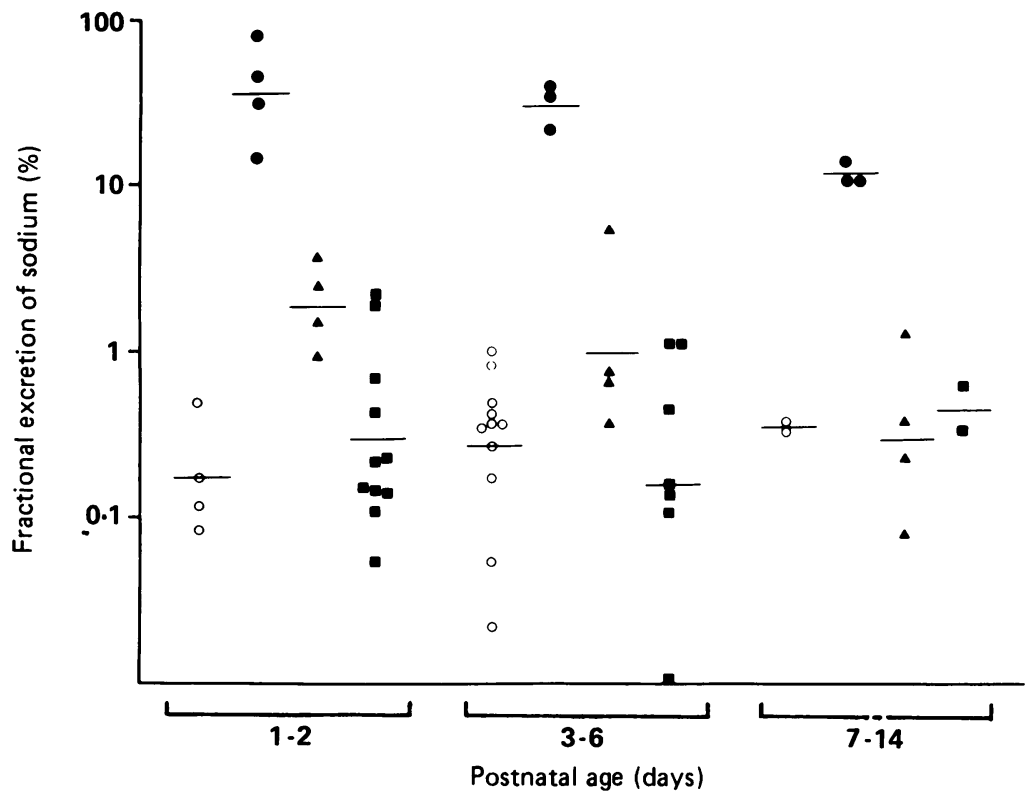

Figure 4 Fractional excretion of sodium with increasing postnatal age in control subjects (open symbols) and asphyxiated infants (closed symbols-group 1: circles, group 2: triangles, and group 3: squares). The scale is logarithmic and the horizontal bars indicate the mean for each group.

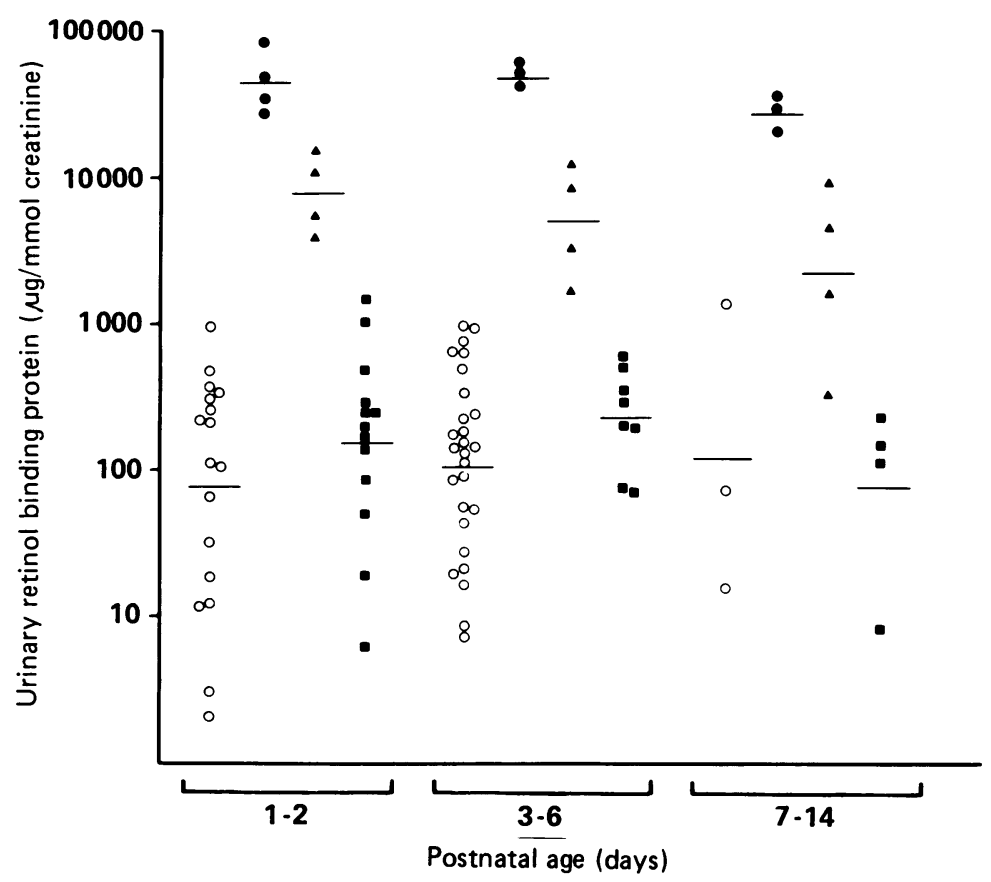

Figure 5 Urinary excretion of retinol binding protein with increasing postnatal age in control subjects (open symbols) and asphyxiated infants (closed symbols-group 1: circles, group 2: triangles, and group 3: squares). The scale is logarithmic and the horizontal bars indicate the mean for each group. asphyxiated infants are considered in these three subgroups.

Plasma creatinine values in control infants and in the asphyxiated infants studied serially are shown in fig 2 . Infants in group 1 already had greatly increased plasma creatinine concentrations during the first two days of life, which increased further towards the end of the first week and then declined during the second week. Infants in groups 2 and 3 showed the expected decline in plasma creatinine concentration with increasing postnatal age.

Creatinine clearance during the first two days of life, expressed according to birth weight, was correspondingly reduced in group 1 ; all these infants were oliguric at the time of initial assessment with urinary flow rates of less than $1 \mathrm{ml} / \mathrm{kg}$ /hour (fig 3).

Tubular dysfunction was confirmed in groups 1 and 2 by the fractional excretion of sodium (fig 4).

In control infants the mean urinary excretion of retinol binding protein and myoglobin, and the fractional excretion of sodium were constant during the first two weeks of life; NAG excretion showed a slight rise with increasing postnatal age. Myoglobin was detected in the urine of only one control infant, between 3 and 6 days: the concentration was at the limit of the assay and the infant did not show the highest concentration of retinol binding protein or of NAG in the control group. In infants in group 1 the mean excretion of all markers declined towards their respective normal ranges with increasing time after the episode of asphyxia, the retinol binding protein most slowly. The same was true of group 2 with the exception of NAG, the mean excretion of which remained unchanged. Excretion of all markers in group 3 was comparable with control values throughout the first two weeks of life (fig 5, 6, and 7).

Free myoglobin seems to be handled by the kidney as a low molecular weight protein, in a similar way to retinol binding protein. In the presence of an increased filtered load (a raised plasma concentration) it appears in the urine in detectable quantities in the presence of tubular dysfunction, as indicated by an increased urinary retinol binding protein concentration.

Plasma myoglobin concentration was greatly increased in infants in group 1 (fig 8), but concentrations decreased in all groups with increasing postnatal age.

\section{Discussion}

The measurement of various tubular markers of renal function has proved useful in the diagnosis and surveillance of a number of renal disorders. ${ }^{30-33}$ Low molecular weight proteins, such as $\beta_{2}$-microglobulin and retinol binding protein, are freely filtered at the glomerulus and almost completely reabsorbed by the proximal tubular cells in health, so that when tubular dysfunction is present, increased quantities appear in the urine. The report of raised urinary $\beta_{2}$-microglobulin concentrations in infants with meconium stained liquor who were otherwise well led to the suggestion that subclinical tubular damage was present in a proportion of these infants, and that measurement of low 


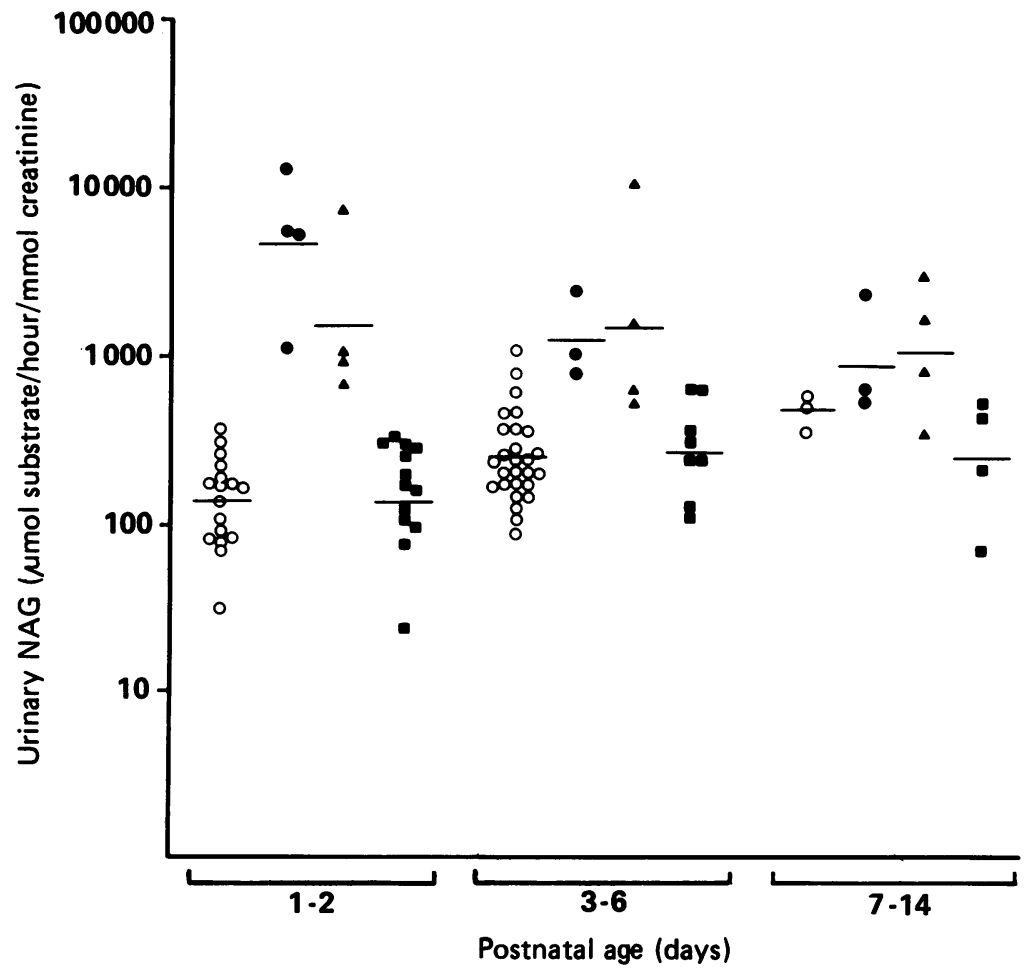

Figure 6 Urinary excretion of $N$-acetyl- $\beta$-D-glucosaminidase (NAG) with increasing postmatal age in control subjects (open symbols) and asphyxiated infants (closed symbolsgroup 1: circles, group 2: triangles, and group 3: squares). The scale is logarithmic and the horizontal bars indicate the mean for each group.

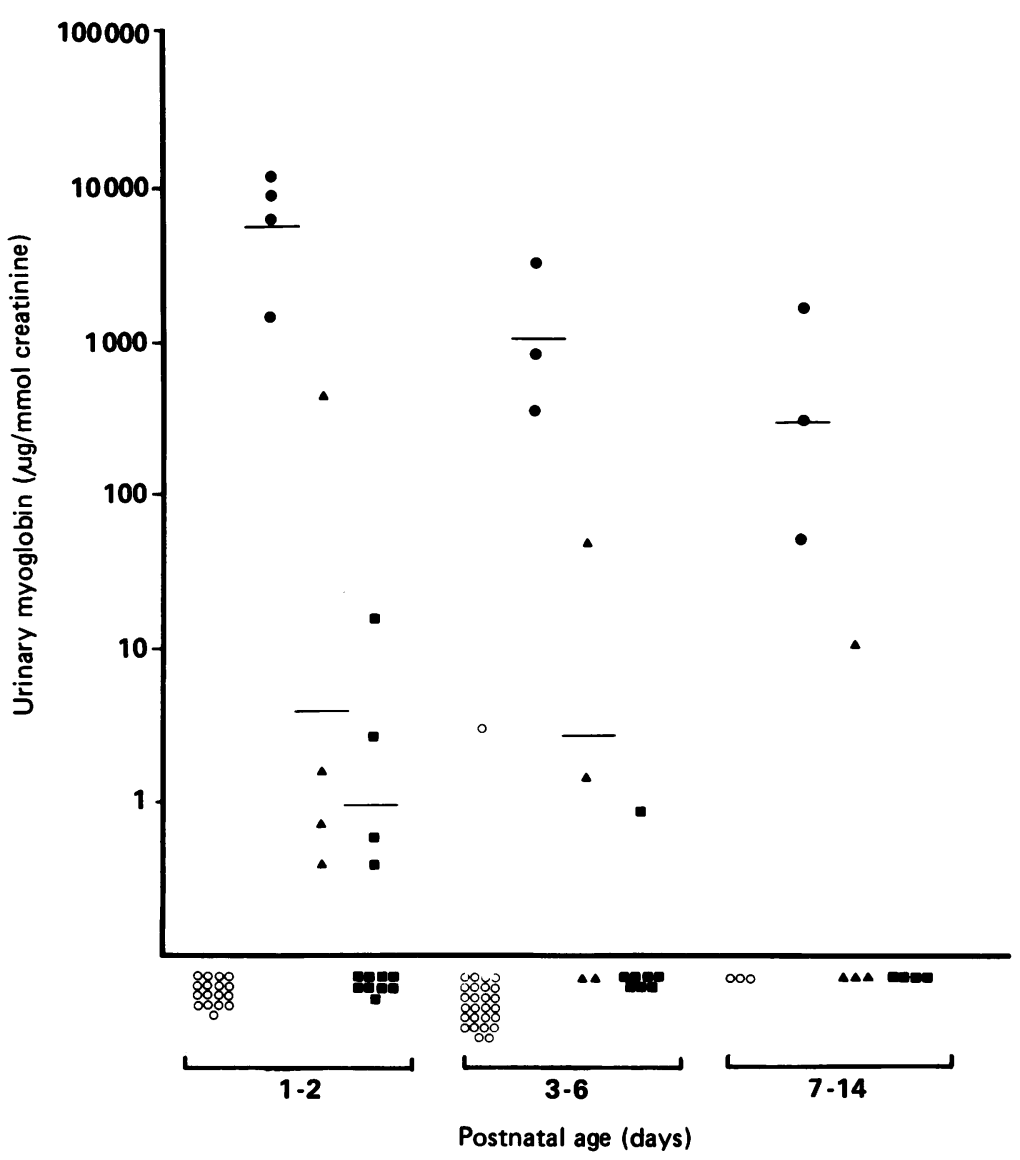

Figure 7 Urinary excretion of myoglobin with increasing postnatal age in control subjects (open symbols) and asphyxiated infants (closed symbols-group 1: circles, group 2: triangles, and group 3: squares). The scale is logarithmic and the horizontal bars indicate the mean for each group. molecular proteinuria might be a useful adjunct in the assessment of their renal function.?

Comparison data from studies in adults have shown that urinary retinol binding protein concentration correlates well with that of $\beta_{2^{-}}$ microglobulin, and that it is of equal sensitivity in the detection of tubular dysfunction. ${ }^{34}$ We chose to measure retinol binding protein because it is stable at lower urinary $\mathrm{pH}$ values at which degradation of $\beta_{2}$-microglobulin occurs, and the need for manipulation of urinary $\mathrm{pH}$ on voided specimens is eliminated. ${ }^{35}$

Excretion of retinol binding protein in neonates is higher than in adults. Our control infants achieved a mean retinol binding protein excretion in the first two days of life of 75 $\mu \mathrm{g} / \mathrm{mmol}$ creatinine, with similar values in the second week of life, in contrast to a reported mean concentration of $7 \cdot 7 \mu \mathrm{g} / \mathrm{mmol}$ creatinine in adult men. ${ }^{28}$ This tenfold difference is not a spurious increase in the retinol binding protein concentration as a result of the lower urinary creatinine concentrations found in infants; the absolute urinary retinol binding protein concentrations in the infants were greater, with a maximal recorded value of $4000 \mu \mathrm{g} / \mathrm{l}$, compared with the maximal normal adult value reported in the above study of $540 \mu \mathrm{g} / \mathrm{l}$. This presumably reflects reduced proximal tubular reabsorption in neonates.

The mean retinol binding protein excretion reported here for control infants with gestational ages of more than 34 weeks is similar to the value obtained by Clark $e t a l,{ }^{36}$ but out upper tolerance limit of normal is roughly five times higher and reflects a greater range of retinol binding protein excretion values in the group studied.

We identified three groups of asphyxiated infants according to their urinary retinol binding protein:creatinine ratio. The four infants with acute renal failure had the highest excretion (range 27 759-81 $112 \mu \mathrm{g} / \mathrm{mmol}$ creatinine) and there was clear discrimination between these infants and the others. In turn, infants in group 2(3721-15 243) were clearly differentiated from those in group 3 (6-1418). Infants with acute renal failure also had the heaviest myoglobinuria (range 1526-13 $195 \mu \mathrm{g} / \mathrm{mmol}$ creatinine) and, as with retinol binding protein, were sharply distinguished from the others. Those in group 2 had detectable, but lesser, degrees of myoglobinuria $(0 \cdot 4-430)$. Gross pigmenturia, giving a brown colour to the urine, was seen in all infants in group 1, and in the infant from group 2 who had the highest myoglobin concentration of that group. In three infants from group 3 myoglobin was detected in the urine, but the values were at the limit of detection. Our results are in agreement with those of Kojima et al. ${ }^{20}$ Tubular dysfunction was confirmed by the fractional excretion of sodium, which was grossly abnormal in group 1 (mean $31.9 \%$ ) mildly increased in group $2(1.7 \%)$, and normal in group $3(0.3 \%)$. That in control infants was below $1 \%$ and in sodium balance studies the fractional excretion of sodium in healthy infants of similar gestational age with a sodium intake of $\leqslant 2.5 \mathrm{mmol} / \mathrm{kg} /$ day has been reported to be normally less than $1 \% .{ }^{17}$ 


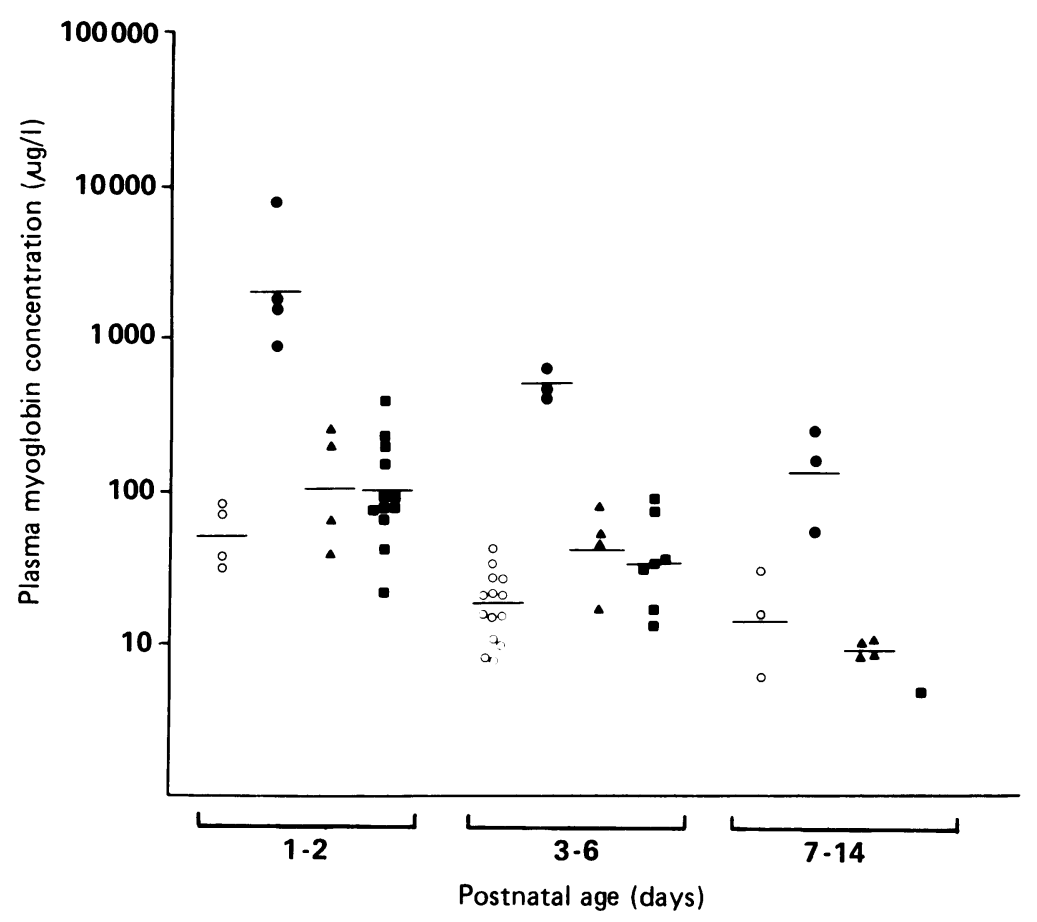

Figure 8 Plasma myoglobin concentrations with increasing postnatal age in control subjects (open symbols) and asphyxiated infants (closed symbols-group 1: circles, group 2: triangles, and group 3: squares). The scale is logarithmic and the horizontal bars indicate the mean for each group. constant mean values throughout the two week postnatal period in infants in group 2, supports this suggestion. In these infants retinol binding protein and myoglobin excretion steadily declined, and by the second week remained high in only one infant; measurements were repeated in the third week in this infant and all results were then normal. This indicates that tubular dysfunction in these infants is transient. Infants in group 3 had concentrations comparable with those in control infants throughout the study.

Our single criterion for the diagnosis of acute renal failure was a plasma creatinine concentration of over $130 \mu \mathrm{mol} / 1$ for at least two days. The presence of oliguria was not required so we did not overlook infants with non-oliguric acute renal failure. Similar plasma creatinine concentrations have been used as diagnostic criteria in other studies. ${ }^{1239}$ We measured plasma creatinine using high performance liquid chromatography because the method is specific; with modified Jaffé techniques various chromogens present in plasma interfere with the reaction resulting in overestimations or underestimations of the creatinine concentration that cannot be predicted for any individual measurement and may produce errors in excess of $100 \%$. ${ }^{40}$ Within two days, the plasma creatinine concentrations in infants in group 1 were considerably raised (mean $257 \mu \mathrm{mol} / \mathrm{l}$ ). The mean values were similar in groups 2 and 3 , comparable to our limited control data, and within the expected range for infants of similar postnatal age reported by other workers. ${ }^{11} 12$ Creatinine clearance expressed according to birth weight, ${ }^{41}$ was correspondingly reduced (mean $0.01 \mathrm{ml} / \mathrm{min} / \mathrm{kg}$ ) in group 1 . The clearances measured in groups $2(0 \cdot 8)$, and $3(1 \cdot 2)$, are similar to those described by Coulthard in a review of published data on glomerular filtration rates expressed by birth weight in healthy newborns. ${ }^{42}$

All infants in group 1 were oliguric in the first two days of life with urinary flow rates of less than $1 \mathrm{ml} / \mathrm{kg} /$ hour. One infant from group $3 \mathrm{had}$ a reduced urine output, the remainder had flow rates in excess of $1 \mathrm{ml} / \mathrm{kg} /$ hour.

Severe muscle damage associated with subsequent renal failure is well documented in adults, ${ }^{18}$ and the same phenomenon probably occurs in neonates. ${ }^{43}$ Birth asphyxia is associated with myoglobinaemia in the first few days of life, the severity of which is-in turn-related to the duration of postnatal oliguria. ${ }^{19}$ Plasma myoglobin concentrations, measured in the first 2 days of life in our asphyxiated infants, ranged from 21 to $7625 \mu \mathrm{g} / \mathrm{l}$. The infants with acute renal failure had the highest concentrations, and the infant who required dialysis had the highest of all. These concentrations are similar to those reported by Kasik et $a l,{ }^{19}$ and similar to those seen in adults with acute rhabdomyolysis and acute renal failure. ${ }^{44} \mathrm{At}$ birth, infant muscle contains roughly $10 \%$ of the adult myoglobin content ${ }^{45}$; the plasma concentrations achieved by several of the asphyxiated infants therefore indicate considerable muscle breakdown.

If the normal range of plasma creatinine at birth and an expected daily rise above $18 \mu \mathrm{mol} / \mathrm{l}$ 
in the presence of acute renal failure are considered, ${ }^{46}$ the plasma creatinine concentrations in our infants represent an extremely rapid rise. Such a rise has been reported in myoglobinuric renal failure in adults, and is the result of the release of large quantities of intracellular creatine from damaged muscle. ${ }^{47}$ Our results show that an asphyxial insult may be associated with tubular dysfunction, but that acute renal failure supervenes only in the presence of high plasma concentrations of myoglobin: the exaggerated rise in plasma creatinine in our infants, coupled with the heavy myoglobinaemia and myoglobinuria, suggests that these infants had rhabdomyolysis induced renal failure.

Our identification of infants with no glomerular disturbance but with detectable tubular dysfunction confirms previous reports, although this was a less common occurrence in our study $(19 \%)$ than in others. ${ }^{78}$ Plasma myoglobin concentrations in these infants were lower than in those with acute renal failure, evidence that they sustained less severe asphyxial damage. These infants undoubtedly have a degree of tubular dysfunction that is clinically unsuspected but which can be shown with sensitive tests. The higher mean fractional excretion of sodium in this group of infants has implications for electrolyte balance, although we found no significant differences in the plasma sodium and potassium concentrations between these infants and those without tubular dysfunction during the time periods $1-2$ and 3-6 days (Wilcoxon rank sum test with correction factor).

In conclusion, $62 \%$ of the infants studied, who were over 34 weeks' gestational age and had had an episode of birth asphyxia, showed no apparent impairment of renal function, $19 \%$ had overt acute renal failure, and a further 19\% had tubular dysfunction indicated by an increased excretion of tubular proteins, but without any associated glomerular disturbance. These figures do not represent the absolute incidence of renal damage in our units because the numbers presented here include infants not born in the hospital and exclude those who received treatment with aminoglycoside antibiotics.

Infants with acute renal failure were clearly identified by their increased excretion of retinol binding protein and myoglobin. Urinary retinol binding protein:creatinine ratios in excess of $27000 \mu \mathrm{g} / \mathrm{mmol}$ creatinine, and urinary myoglobin:creatinine in excess of $1500 \mu \mathrm{g} / \mathrm{mmol}$ creatinine seem to be of diagnostic value. NAG excretion, although a sensitive indicator of tubular injury, is not specific for acute renal failure.

Plasma creatinine concentration, creatinine clearance, and fractional excretion of sodium defined the group with acute renal failure, but all have some disadvantage that affects their potential diagnostic value. The HPLC method we used, which measures 'true' plasma creatinine is of restricted availability; creatinine clearance is subject to the added inaccuracies incumbent upon timed urine collections and incomplete bladder emptying, ${ }^{48}$ and the measurement of the fractional excretion of sodium requires simultaneous blood and urine samples and cautious interpretation when diuretics or a saline load have been administered.

The measurement of retinol binding protein or myoglobin is simple, inexpensive, and can be carried out on random samples of urine. We suggest that the measurement of retinol binding protein or myoglobin should be incorporated into the routine assessment of asphyxiated infants at birth, as they give an early indication of the adequacy of renal function. We thank the parents and participating infants for their help and
understanding. We thank sisters B Clarkson-White and B Nichol understanding. We thank sisters B Clarkson-White and B Nichol and all staff of the neonatal units of

This study was supported in part by the Children Nationwide This study was supported in part by the Children Nationwide
Medical Research Fund. DS Roberts was supported by St Thomas's Hospital Research Endowment Fund.

1 Chevalier RL, Campbell F, Brenbridge ANAG. Prognostic factors in neonatal acute renal failure. Pediatrics $1984 ; 74$ : 265-72.

2 Anand SK, Northway JD, Crussi FG. Acute renal failure in newborn infants. $\mathcal{f}$ Pediatr 1978;92:985-8.

3 Anand SK. Acute renal failure in the neonate. Pediatr Clin North Am 1982;29:791-800.

4 Dauber IM, Krauss AN, Symchych PS, Auld PA. Renal failure following perinatal anoxia. $\mathcal{F}$ Pediatr 1976;88:851-5. 5 Meeks ACG, Sims DG. Treatment of renal failure in neonates. Arch Dis Child 1988;63:1372-6.

6 Stapleton FB, Jones DP, Green RS. Acute renal failure in neonates: incidence, etiology and outcome. Pediatric Nephrology 1987;1:314-20.

7 Cole JW, Portman RJ, Lim Y, Perlman JM, Robson AM. Urinary $\beta 2$-microglobulin in full-term newborns: evidence for proximal tubular dysfunction in infants with meconiumstained liquor. Pediatrics 1985;76:958-64.

8 Tack ED, Perlman JM, Robson AM. Renal injury in sick newborn infants: a prospective evaluation using urinary $\beta 2$ mewborn infants: a prospective evaluation using urinary $\beta 2-$

microglobulin concentrations. Pediatrics $1988 ; 81: 432-40$.
9 Sherry SN, Kramer I. The time of passage of first stool and first urine by the newborn infant. $\mathcal{f}$ Pediatr $1955 ; 46: 158$.

10 Grylack L, Medani C, Hultzen C, Sivasubramanian K, Davitt MK, Scanlon JW. Nonoliguric acute renal failure in the newborn. A prospective evaluation of diagnostic indexes. the newborn. A prospective evaluatio

1 Trompeter RS, Al-Dahhan J, Haycock GB, Chik G, Chantler C. Normal values for plasma creatinine concentration related to maturity in normal term and preterm infants. Int f Pediatr Nephrol 1983;4:145-8

12 Rudd GD, Hughes EA, Placzek MM, Hodes DT. Reference ranges for plasma creatinine during the first month of life. Arch Dis Child 1983;58:212-5.

13 Spencer K. Analytical reviews in clinical biochemistry: the estimation of creatinine. Ann Clin Biochem 1986;23:1-25.

14 Matthew OP, Jones AS, James E, Bland H, Groshong T. Neonatal renal failure: usefulness of diagnostic indices. Pediatrics 1980;65:57-60

15 Norman ME, Asadi FK. A prospective study of acute renal failure in the newborn infant. Pediatrics 1979;63:475-9.

16 Ellis EN, Arnold WC. Use of urinary indexes in renal failure in the newborn. Am $\mathcal{F}$ Dis Child 1982;136:615-7.

17 Al-Dahhan J, Haycock GB, Chantler C, Stimmler L. Sodium homeostasis in term and preterm neonates: 1 Renal aspects. Arch Dis Child 1983;58:335-45.

18 Bywaters EGL, Beall D. Crush injuries with impairment of renal function. Br Med $\mathcal{F} 1941 ; 1: 427-32$.

19 Kasik JW, Leuschen MP, Bolam DL, Nelson RM. Rhabdomyloysis and myoglobinaemia in neonates. Pediatrics 1985; 76:255-8.

20 Kojima T, Kobayashi T, Matsuzaki S, Iwase S, Kobayashi Y. Effects of perinatal asphyxia and myoglobinuria on development of acute renal failure. Arch Dis Child 1985;60: 908-12.

21 Potter EL, Thierstein ST. Glomerular development in the kidney as an index of fetal maturity. F Pediatr 1943;22:695.

22 Dubowitz LMS, Dubowitz V, Goldberg C. Clinical assessment of gestational age in the newborn infant. $\mathcal{f}$ Pediatr ment of gesta

23 Tarlow M. Urine and stool collection for metabolic studies in the newborn. Arch Dis Child 1974;49:490-2.

24 Elinder G, Aperia A. Development of glomerular filtration rate and excretion of $\beta 2$-microglobulin in neonates during rate and excretion of $\beta 2$-microglobulin in neonates during

25 Osborne JP. Urinary enzymes in the detection of renal damage in the newborn. London: University of London, 1980. (MD thesis.)

26 Ambrose RT, Ketchum DF, Smith JW. Creatinine determined by 'high-performance' liquid chromatography. Clin Chem 1983;29:256-9.

27 Cook JGH. Creatinine assay in the presence of protein. Clin Chim Acta 1972;47:613-7.

28 Topping MD, Forster HW, Dolman D, Luczynska CM Bernard AM. Measurement of urinary retinol-binding protein by enzyme-linked immunosorbent assay and its 
application to the detection of tubular proteinuria. Clin Chem 1986;32:1863-6.

29 Marulin D. Rapid colorimetric assay of $\beta$-D-galactosidase and $\mathrm{N}$-acetyl- $\beta$-D-glucosaminidase in human urine. Clin Chim Acta 1976;73:453-61.

30 Wellwood JM, Ellis BG, Price RG, Hammond K, Thompson $\mathrm{AE}$, Jones NF. Urinary $\mathrm{N}$-acetyl- $\beta$-D-glucosaminidase activities in patients with renal disease. Br Med $\mathcal{F} 1975$;iii: 408-11.

31 Kunin CM, Chesney RW, Craig WA, England AC, DeAngelis $C$. Enzymuria as a marker of renal injury and disease studies of $\mathrm{N}$-acetyl- $\beta$-D-glucosaminidase in the general population and in patients with renal disease. Pediatrics 1978;62:751-60.

32 Watanabe K, Kojima T, Fukuda Y, et al. Reliability of urinary $\mathrm{N}$-acetyl- $\beta$-D-glucosaminidase as an indicator of renal tubular damage in neonates. Biol Neonate 1987;52: $16-21$.

33 Gibb DM, Tomlinson PA, Dalton NR, Turner C, Shah V, Barratt TM. Renal tubular proteinuria and microBarratt TM. Renal tubular proteinuria and microalbuminuri

34 Bernard AM, Moreau D, Lauwerys R. Comparison of retinol-binding protein and $\beta 2$-microglobulin determination in urine for the early detection of tubular proteinuria. Clin Chim Acta 1982;24:477-82.

35 Davey PG, Gosling P. $\beta 2$-microglobulin instability in pathological urine. Clin Chem 1982;28:1330-3.

36 Clark PMR, Bryant TN, Hall MA, Lowes JA, Rowe DJF Neonatal renal function assessment. Arch Dis Child 1989; 64:1264-9.

37 Schlesinger P, Rodman JS, Frey M, et al. Clearance of lysosomal hydrolases following intravenous infusion, the role of the liver in the clearance of $\beta$-glucuronidase and $\mathrm{N}$ -

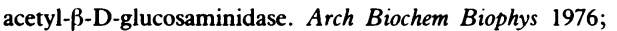
177:606-14.

38 Bernard A, Amor AL, Viau C, Lauwerys R. The renal uptake of proteins: a non-selective process in conscious rats. Kidney Int 1988:34:175-85.

39 Olavarria F, Krause S, Barranco L, et al. Renal function in full-term newborns following neonatal asphyxia. Clin Pediatr 1987;26:334-8.

40 Huang Y, Chiou WL. Creatinine XII: comparison of assays of low serum creatinine levels using high-performance liquid chromatography and two picrate methods. $\mathcal{J}$ Pharm Sci 1983;72:836-7.

41 Coulthard MG, Hay EN. Weight as the best standard for glomerular filtration in the newborn. Arch Dis Child 1984;59:373-5.

42 Coulthard MG. The maturation of glomerular filtration in preterm and mature babies. Early Hum Dev 1985;11: preterm

43 Haftel AJ, Eichner J, Haling J, Wilson ML Myoglobinuric renal failure in a newborn infant. F Pediatr 1978;93:1015-6. 44 Demos MA, Gitin EL, Kagen LJ. Exercise myoglobinemia and acute exertional rhabdomyolysis. Arch Intern Med and acute exertiona

45 Kagen LJ, Christian CL. Immunologic measurements of myogloblin in human adult and fetal skeletal muscle. $A m \mathcal{F}$ Physiol 1966;211:656-60.

46 Guignard JP. Neonatal nephrology. In: Holliday MA, Barrat TM, Vernier RL, eds. Pediatric nephrology. 2nd Ed Baltimore: Williams and Wilkins, 1987: $921-44$.

47 Grossman RA, Hamilton RW, Morse BM, Penn AS, Goldberg $M$. Nontraumatic rhabdomyolysis and acute renal failure. $N$ Engl $\mathcal{f}$ Med 1974;291:807-11.

48 Roberts DS, Rendell B. Postmicturition residual bladder volumes in healthy babies. Arch Dis Child 1989;64:825-8. 